Jpn. J. Limnol., 48, 1, 19-24, 1987.

\title{
淀川に抢ける水の混合・拡散について
}

\author{
五百井正樹・串部宏之・北田忠義 - 建部 渉 - 前田礼造 - 人見宗男
}

\section{The Mixing of River Water in River Yodo}

\author{
Masaki IoI, Hiroyuki Kushibe, Tadayoshi Kitada, Wataru Tatebe, \\ Reizo MaEda and Muneo Hitomi
}

\begin{abstract}
Using dissolved conservative constituents in river waters, the mixing of flowing waters was studied between $13 \mathrm{~km}$ downstream and the junction where the River Kizu from left side, the River Uji from the middle, and the River Katsura from the right side, converge to form the River Yodo.

The concentrations of ammonium, phosphate, sodium and potassium in river waters on the right side of the River Yodo were always higher than those found on the left side to about $13 \mathrm{~km}$ downstream. The amounts of silica, sodium and potassium calculated from their concentrations and flow volume in the River Yodo were in good agreement with the sum of their amounts from the three tributaries. Using each flow volume estimated from the concentrations of silica and sodium (or potassium) in tributaries, the contribution ratio of ammonium and phosphate loading to the River Yodo was calculated and found to be in good agreement with the measured loadings.

The present results suggested that the removal of ammonium and phosphate during flow downstream might not occur, and silica can be used as a conservative tracer of flowing water mixing as well as sodium and potassium.
\end{abstract}

Key words : River Yodo, water mixing, conservative tracer, silica.

\section{1. 緒言}

近年水需要の増大に伴い, 污染負荷源の下流に上水 取水口を開く事例が増えている。このことは中流に大 都市を持つ淀川水系で著しく，下流部での取水水質へ の影響をできる限り小さくするためには, 淀川での水 の混合・拡散についての知識が不可欠と言える。 淀川に打壮る水の混合・払散については南部 (1960) の報告があるが, 実際上への適用にはやや困難さがと もなう。更に河川に打ける水の混合・拡散は河川の流 況, 流量等による影響を受けるものであり, 現在の淀 川の流況は当時と同じではない。

南部はリシウムを淀川に流入する小河川に投入し， それを指標として追跡する手法によったが，そのよう な手法は今は, とりわけ水量の多い河川については, 望むべくもない。それゆ光, 水の混合についての検討 はまず，河川水中に存在する物質あるい肳理量のう らから指標となりらる物質あるいは物理量を見出すこ とから始まる。もとよりそれらの量は保存量でなけれ ばならず，更に対象とする河川間の水質の相違をよく
表しらるものでなければならない。

われわれは，木津川，宇治川および桂川の三河川の 混合について検討し， $\mathrm{Na} ＼textrm{K}$ および $\mathrm{Si}$ がよい指標と なりらることを見出したが，ここで用いたわれわれの 手法は他の河川についても応用が可能であろう。

\section{2. 測定方法}

Figure 1 に示す測点に括いて, 1984 年 8 月, 10 月, 1985 年 1 月， 4 月， 5 月， 7 月および 11 月において採 水，栄養塩類， Na および $\mathrm{K}$ たついて分析を行なった。 また， 1985 年 5 月，淀川に打ける水質の時間変動を見 るため 4 時間間隔で 6 回の採水を, 枚方大橋左岸部 （St. 16）で行なった。採取した試料は氷温で保存し, 栄養塩類の分析に供する試料はガラス繊維ロ紙（ワッ トマン $\mathrm{GF} / \mathrm{C})$ により濾過，原則として採取後 24 時間 以内に分析に供した。分析までにそれ以上の時間を置 く場合は試料を $-20^{\circ} \mathrm{C}$ で涷結保存した。分析は, テク ニコン社製オートアナライザーによった。 $\mathrm{Na}, \mathrm{K}$ の分 析に供する試料は濾紙 (東洋, No. 5 c) による濾過後 塩酸酸性とし, 発光分光分析にかけた。 


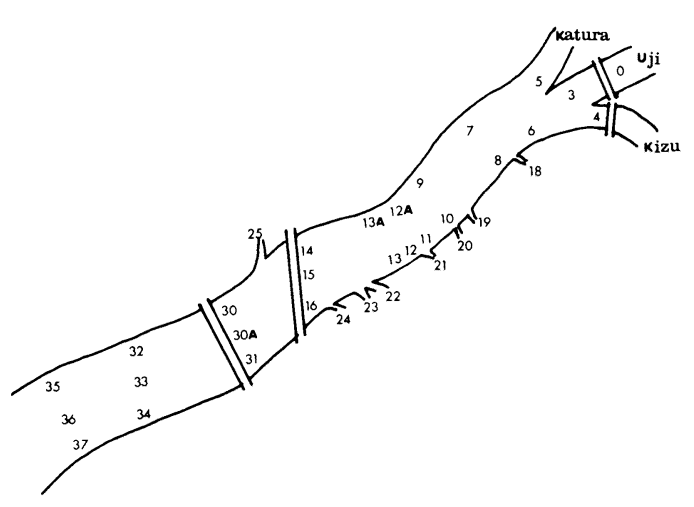

Fig. 1. The map of sampling sites at River Yodo.

採水は主としてボートにより，上流から下流にかけ 行なった。下流部の一部測点においては, プラスチッ ク製採取水器による橋からの採水によった。採水は原 則として水面下 $50 \mathrm{~cm}$ で行なった。採水時間を水の流 下時間に正確には合わせることはできなかったが，後 に示すように水質の時間変動は採水時間の範囲内にお いてきわめて小さかった。

木津川, 宇治川, 桂川および淀川の水量は, 八幡, 淀, 納所および枚方における水位をもとに, 1983 年度 の計算式を用いて算出した。流入小河川の水量は測定 した流速をもとに算出した。

\section{3. 結 果}

\section{3-1. 三川および淀川の水質}

7 回の測定のらち, 1985 年 1 月の結果の一部を Fig. 2 に示した。溶存態無機チッソ (DIN), $\mathrm{PO}_{4}, \mathrm{Na}$ お よび $\mathrm{K}$ の濃度は三川のらち桂川に拈いて高く宇治川お よび木津川において低かった。また $\mathrm{SiO}_{2}$ は木津川およ び桂川で高く宇治川で低かった。この傾向はいずれの 測定時においても共通に認められた。測定項目間の相 関は Table 1 に例示する通り, $\mathrm{SiO}_{2}$ に関係するもの以 外はきわめて高かった。

淀川における物質濃度の分布は, DIN, $\mathrm{NH}_{3}$, $\mathrm{PO}_{4}, \mathrm{Na}, \mathrm{K}$ については右岸部で高く, $\mathrm{SiO}_{2}$ にいて は左岸および右岸部で高かった。この河川の横断方向 における濃度差は下流に向からにつれ減少しいずれの 調査時においても, 合流後約 $13 \mathrm{~km}$ 下流の淀川新橋 (St. 30〜31) に至るとほとんど認められなくなった。 $\mathrm{Na}$ および $\mathrm{SiO}_{2}$ について, この関係を Fig. 3 に例示し た。

Station 16 における水質の時間変動はいずれの測定 項目についても小さく，とりわけ $\mathrm{Na}, \mathrm{K}$ および $\mathrm{SiO}_{2}$ については $3 \%$ 未満であった。COD, DO等について も, 時間変動の小さいことが報告されている（大阪工 大・応用化学研, 1985)。
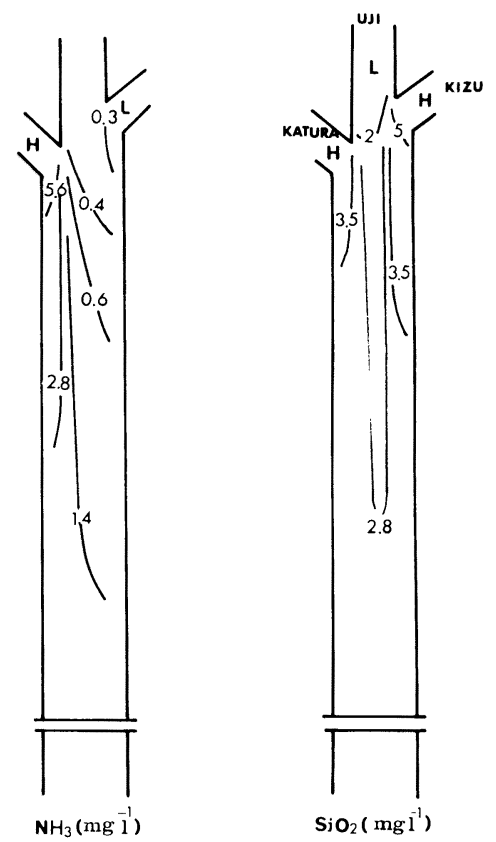

Fig. 2. Distributions of the concentrations of $\mathrm{NH}_{3}$ and $\mathrm{SiO}_{2}$ at River Yodo in January 1985.

Table 1. Correlation coefficients between concentrations of some substances at River Yodo.

\begin{tabular}{l|cccccc}
\hline & $\mathrm{NH}_{3}$ & $\mathrm{NO}_{3}$ & $\mathrm{PO}_{4}$ & $\mathrm{SiO}_{2}$ & $\mathrm{Na}$ & $\mathrm{K}$ \\
\hline $\mathrm{NH}_{3}$ & & & & & & \\
$\mathrm{NO}_{3}$ & 0.798 & & & & & \\
$\mathrm{PO}_{4}$ & 0.947 & 0.814 & & & & \\
$\mathrm{SiO}_{2}$ & 0.367 & 0.792 & 0.394 & & & \\
$\mathrm{Na}$ & 0.930 & 0.876 & 0.973 & 0.473 & & \\
$\mathrm{~K}$ & 0.925 & 0.899 & 0.931 & 0.561 & 0.963 & \\
\hline
\end{tabular}

January $1985 n=47$

\section{3-2. 流入小河川の水質}

淀川に流入する河川はいずれも水量 $1 \mathrm{~m}^{3} \cdot \mathrm{sec}^{-1}$ 前後 の小河川であり, 右岸に流入する芥川（St. 25）を除 き, 家庭排水, 工業排水等の影響による污染の進行が 認められた。小河川からの負荷をTable 2 に例示し た。

\section{4. 検討}

\section{4-1． 物質収支}

淀川における物質収支について検討した。流入負荷 は, 木津川, 宇治川, 桂川および流入小河川について 算出した。ただし, 流入小河川のうちほとんど氷量の ない桧尾川からの負荷は無視した。流出負荷は取水水 量に取水口近傍の物質濃度を乗じることで算出した。 取水量は調査日の実取水量によったが, 当日の取水量 


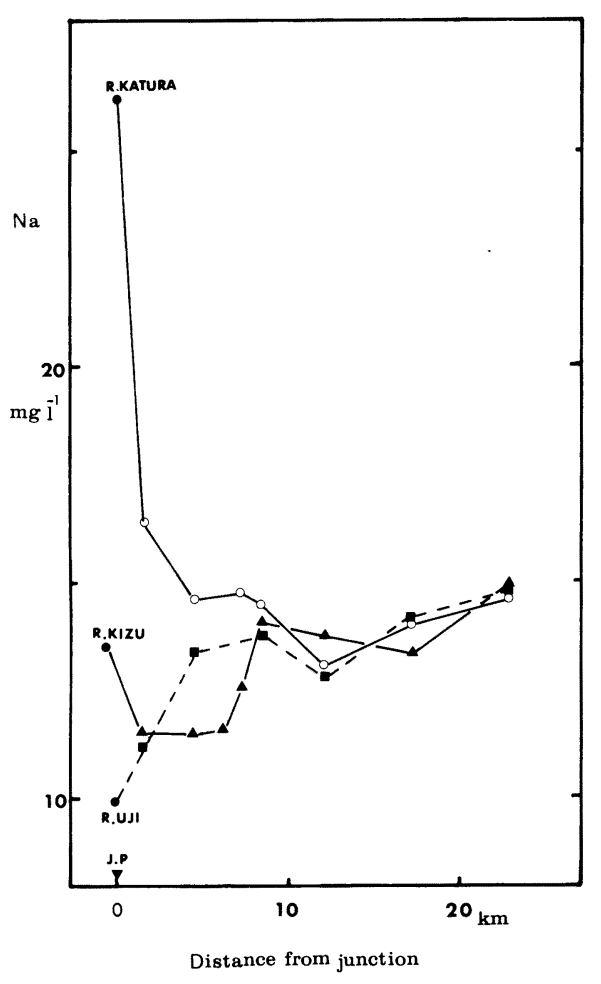

Fig. 3. Change in $\mathrm{Na}$ concentration from junction point toward downstream, $\boldsymbol{\nabla}$ denotes the junction point of three rivers.

$\bigcirc$ : right side, $\mathbf{\Delta}$ : left side, $\mathbf{\square}$ : center in the stream.

についてのデータが入手できない場合は, 取水量には 日ごとの変動が汷とんどないため平均の取水量を用い た。淀川における流下負荷量は淀川新橋（St. 30～31） において算出した。淀川新橋に打ける水量は, 枚方に おける水量に芥川の水量を加光, 木屋に打ける取水量 を差し引くことで求めた。結果のうち, 低水時（1月） と増水時（4月）のものを Table 2 に示した。

Table 中の A は, 流入小河川による負荷の流入負荷 総量に対する比率であり，Bは算出した負荷量（流入 負荷量一流出負荷量）と淀川新橋に拈いて㬰測した負 荷量との差の, 算出した負荷量に対する比率である。 いずれの場合も水収支について良い一致が得られた。 流入小河川による負荷の総流入負荷量に対する比率は, $\mathrm{NH}_{3}, \mathrm{PO}_{4}$ を除いては小さく $\mathrm{Na}, \mathrm{K}$ 拈よび $\mathrm{SiO}_{2}$ につ いては $10 \%$ 未満となった。正味負荷量と流下負荷量と の差は, $\mathrm{NH}_{3}$ についてはやや大きかったが, $\mathrm{Na}, \mathrm{K}$ および $\mathrm{SiO}_{2}$ については, 1 月の $\mathrm{Na}$ の結果を除くと, 水収支の差と同程度であった。このことはこれら物質 の淀川における保存性の高さを示すものと言えよう。

$\mathrm{Na}$ およびKは一般に不活性物質とされており上記 の結果とよく整合するが， $\mathrm{SiO}_{2}$ は一般に不活性物質と
は言觉ない。すなわち $\mathrm{SiO}_{2}$ は, 生態系において生化学 的・物理化学的物質循環系に組又込まれている。しか し，ある物質が生態系において保存性と見なせるかど らかは無前提的に決まるものではなく, 注目する生態 系に扣けるその物質の存在量と循環速度との関係に よって決まることになる。すなわちこの場合, 淀川に おける流下量に比べて循環速度が十分に小さければ， その物質は保存性が高いと見なすことができる。

$\mathrm{SiO}_{2}$ について，その循環速度を決める最大の要因は 有殼藻類，とりわけケイ藻により取込みとその分解に ともなら放出と考兄られる。淀川に拈ける付着藻類の 生体量の測定値は見当たらないものの，多くの時期に おいては生体量は平衡にあるものと考えられ，生体量 が平衡にあるなら藻類による物質の正味の取込みは生 じえない。生体量が平衡にないと仮定するときの $\mathrm{SiO}_{2}$ の取込み速度について検討した。

富栄養化の進んだ多摩川の河川水を用いた実験によ れば, 付着生体量は新しい付着面において約 2 週間で 最大に達し，この間の付着速度は炭素としておよそ $0.7 \mathrm{~g} \cdot \mathrm{m}^{-2} \cdot \mathrm{day}^{-1}$ となっている（AIZAKI，1985）。付着 生物が全てヶイ藻であると仮定しても，この間のケイ 藻の取込及速度は $0.5 \mathrm{~g} \cdot \mathrm{m}^{-2} \cdot \mathrm{day}^{-1}$ 程度とみつもるこ とができる。[ただし，ケイ藻中の $\mathrm{C} / \mathrm{SiO}_{2}$ を重量比で 0.7 とした（ANTIA et al., 1963）］。淀川を流下する $\mathrm{SiO}_{2}$ 量は河床 $1 \mathrm{~m}^{2}$ たり $10 \mathrm{~g} \mathrm{day}^{-1}$ のオーダーであ り，先に見積もった取込み速度にくらべ十分に大きい 值となる。更にまた, $\mathrm{SiO}_{2}$ の保存性が高ければ $\mathrm{Na}$ と $\mathrm{SiO}_{2}$ 濃度との間には直線関係の成立が期待されるゆ え, 琵琶湖から瀬田川にかけなた宇治川において 各々数地点を選び, $\mathrm{Na}$ および $\mathrm{SiO}_{2}$ 濃度を測定し両者 の関係を見た（Fig. 4)。琵琶湖から瀬田川および宇治 川に颃いて $\mathrm{Na}$ と $\mathrm{SiO}_{2}$ との間には直線関係が成立し た。これらのことは淀川において $\mathrm{SiO}_{2}$ の保存性物質と して取扱いらることを示すものといえよう。

\section{4-2. 淀川における三川の混合}

Figures 2,3に見られる関係は，淀川の水質が桂川， 宇治川および木津川の三川からの水の淀川における混 合の度合によって決まること，またこの混合は淀川新 橋付近でほぼ均一化することを示している。

ここで三川からの河川水の混合について検討した。 流入水量および取水量が既知の場合，ひとつの物質あ るいは物理量を指標として水の混合・㹡散について検 討することができる。しかし流入水量を知ることは必

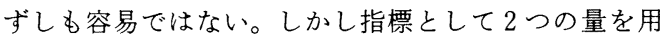
いることが可能であれば，三川の流量等を用いること なく水の混合・抎散について検討しらる。淀川におい ては先に見た通り， $\mathrm{Na}, \mathrm{K}$ および $\mathrm{SiO}_{2}$ 濃度は保存量 と見なすことができ, さらに濃度の時間変動は小さく, かつ三川以外からの流入量は小さい。ただ，淀川水系 においては $\mathrm{Na}$ と $\mathrm{K}$ との相関は極めて高く各々を独立 量として扱うことが困難となっている。また増水時に 
Table 2. Mass balanses at River Yodo.

\begin{tabular}{|c|c|c|c|c|c|c|c|c|c|c|c|c|c|c|c|}
\hline & & & & & anuary & & & & & & & April & & & \\
\hline & Site & Flow & $\mathrm{NH}_{3}$ & DIN & $\mathrm{PO}_{4}$ & $\mathrm{Na}$ & $\mathrm{K}$ & $\mathrm{SiO}_{2}$ & Flow & $\mathrm{NH}_{3}$ & DIN & $\mathrm{PO}_{4}$ & $\mathrm{Na}$ & $\mathrm{K}$ & $\mathrm{SiO}_{2}$ \\
\hline & 3 & 65 & 32.3 & 68.5 & 2.85 & 800 & 154 & 123 & 340 & 39.2 & 172.2 & 4.0 & 2,380 & 598 & 540 \\
\hline & 4 & 17 & 4.2 & 28.0 & 0.34 & 218 & 51 & 89.6 & 97 & 7.0 & 145.6 & 2.7 & 620 & 205 & 540 \\
\hline & 5 & 21 & 119.7 & 165.2 & 7.10 & 716 & 130 & 79.5 & 98 & 50.4 & 159.6 & 8.2 & 870 & 212 & 434 \\
\hline & 18 & 0.34 & 0.84 & 1.4 & 0.09 & 16 & 2 & 5.0 & 2.4 & 2.0 & 5.6 & 0.2 & 40 & 11 & 17 \\
\hline & 19 & 0.01 & 0 & 0 & 0 & 0 & 0 & 0 & 2.0 & 3.6 & 7.0 & 0.5 & 40 & 10 & 8 \\
\hline Influx & 20 & 0.12 & 1.26 & 1.4 & 0.16 & 7 & 1 & 0.8 & 0.4 & 4.9 & 5.6 & 0.7 & 20 & 4 & 3 \\
\hline & 21 & 0.98 & 26.3 & 26.6 & 1.40 & 66 & 14 & 6.7 & 1.2 & 2.8 & 5.6 & 0.5 & 30 & 8 & 8 \\
\hline & 22 & 0.37 & 3.22 & 4.2 & 0.31 & 20 & 4 & 3.4 & 0.8 & 3.6 & 4.2 & 0.4 & 30 & 7 & 6 \\
\hline & 23 & 0.65 & 8.26 & 14.0 & 0.68 & 25 & 6 & 7.8 & 1.6 & 5.5 & 7.0 & 0.4 & 40 & 7 & 17 \\
\hline & 24 & 0.16 & 1.12 & 1.4 & 0.25 & 34 & 2 & 3.1 & 0.3 & 1.5 & 1.4 & 0.3 & 50 & 3 & 6 \\
\hline & 25 & 0.52 & 1.96 & 2.8 & 0.22 & 22 & 3 & 3.4 & 2.5 & 0.6 & 2.8 & 0.1 & 20 & 4 & 17 \\
\hline & Total & 106 & 198.1 & 313.6 & 13.40 & 1,924 & 367 & 329 & 546 & 121.1 & 516.6 & 18.2 & 4,140 & $1,069 \quad 1$ & 1,596 \\
\hline & $\mathrm{A}(\%)$ & 2.8 & 21.1 & 16.5 & 23.1 & 9.9 & 8.7 & 9.2 & 2.0 & 20.2 & 7.6 & 17.7 & 6.5 & 5.1 & 5.1 \\
\hline & 6 & 3.21 & 1.45 & 4.3 & 0.13 & 40 & 8 & 10.7 & 3.2 & 0.3 & 4.2 & 0.1 & 20 & 7 & 3 \\
\hline Outflux & 11 & 12.36 & 11.0 & 21.9 & 0.94 & 197 & 36 & 30.4 & 12.4 & 1.3 & 11.8 & 0.2 & 83 & 25 & 46 \\
\hline & 13 & 1.00 & 2.37 & 3.3 & 0.17 & 19 & 4 & 3.0 & 1.0 & 0.2 & 1.0 & 0.0 & 7 & 2 & 4 \\
\hline & 31 & 0.15 & 0.31 & 0.5 & 0.03 & 3 & 1 & 0.5 & 0.1 & 0.0 & 0.1 & 0.0 & 1 & 0 & 0 \\
\hline & Total & 16.72 & 15.13 & 30.0 & 1.27 & 259 & 48 & 44.6 & 16.7 & 1.9 & 17.1 & 0.3 & 112 & 34 & 53 \\
\hline & Calculated & 89 & 183 & 284 & 12.1 & 1,665 & 319 & 284.8 & 529 & 119.3 & 499.8 & 17.8 & 4,030 & 1,035 & 1,543 \\
\hline Flux & Observed & 82 & 162 & 265 & 13.7 & 1,800 & 291 & 257.1 & 543 & 101.9 & 463.4 & 18.0 & 4,080 & $1,010 \quad 1$ & 1.565 \\
\hline & $\mathrm{B}(\%)$ & -7.9 & -11.5 & -6.9 & 12.8 & 7.8 & -8.8 & -9.7 & 2.6 & -14.6 & -7.3 & 1.0 & 1.2 & -2.4 & 1.5 \\
\hline
\end{tabular}

"Flow" represents in $\mathrm{m}^{3} \mathrm{sec}^{-1}$ and others in $\mathrm{g} \mathrm{sec}^{-1}$.

"A" represents $\{$ influx $(18+19+20+21+22+23+24+25) /$ Total influx $\} \times 100$.

"B" represents (observed flux -calculated flux)/calculated flux $\times 100$.

$\mathrm{SiO}_{2}\left(\mathrm{mg} \cdot \mathrm{l}^{-1}\right)$

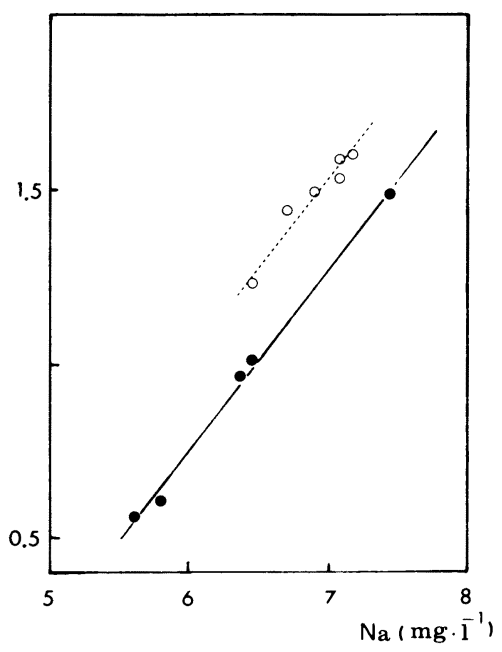

Fig. 4. Relationship between $\mathrm{SiO}_{2}$ and $\mathrm{Na}$ in January 1985
: at Lake Biwa; $\bigcirc$ : at River Uji.
おいては，淀川におけるK の濃度変化は小さく水の混 合・拡散を検討する際の指標として用いるとき誤差が 大きくなる。それゆえ， $\mathrm{Na}$ (あるいはK）および $\mathrm{SiO}_{2}$ を指標して用いることにした。

淀川の任意の地点における木津川，宇治川㧊よび桂 川の混合比を各々 $E 1, E 2, E 3(E 1+E 2+E 3=$ 1）とし，保存性物質 $x, y$ の濃度を $X, Y$ とする。 また木津川，宇治川拉よび桂川における合流点直前の $x, y$ の濃度を $X_{i}, \quad Y_{i}(i=1,2,3)$ とするとき，下 の関係が成立する。

$$
\left(\begin{array}{ccc}
1 & 1 & 1 \\
X 1 & X 2 & X 3 \\
Y 1 & Y 2 & Y 3
\end{array}\right)\left(\begin{array}{l}
E 1 \\
E 2 \\
E 3
\end{array}\right)=\left(\begin{array}{c}
1 \\
X \\
Y
\end{array}\right)
$$

(1)より

$$
\left(\begin{array}{l}
E 1 \\
E 2 \\
E 3
\end{array}\right)=\left(\begin{array}{ccc}
1 & 1 & 1 \\
X 1 & X 2 & X 3 \\
Y 1 & Y 2 & Y 3
\end{array}\right)^{-1}\left(\begin{array}{c}
1 \\
X \\
Y
\end{array}\right)
$$

Equation $(2)$ はまた $(X, Y)$ 座標中の任意の点の座 標を, $(X 1, Y 1)(X 2, Y 2)(X 3, Y 3)$ で構成される 
三角形の面積座標に変換するための式に他ならない。 このとき，淀川内の任意の地点に打けるある河川水の 混合比は, その地点と他の二川の作る三角形の面積の, 三角形全体の面積に対する比となる。

求めた混合比を 1985 年 1 月を例として Fig. 5 に示 す。なお，いずれの測定時においてもほぼ同様の結果 が得られた。また淀川左岸部における木津川水の混合 比の上流から下流にかけての変動を Fig. 6 に示した。 混合比は枚方大橋（St. 16）から淀川新橋（St. 31）に かけてほぼ一定值に収束した。混合比が正しく求めら れている場合, この収束值は木津川の流量比となる。 Station 16 あるいはStation 31 における木津川の混合 比はその流量比をよく反映している。増水時である 4

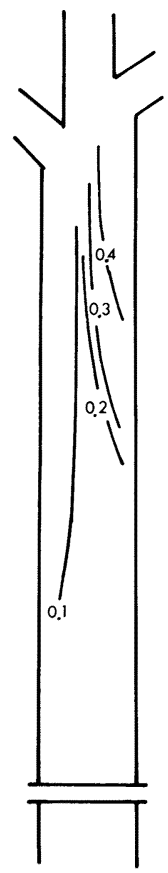

R.Kizu

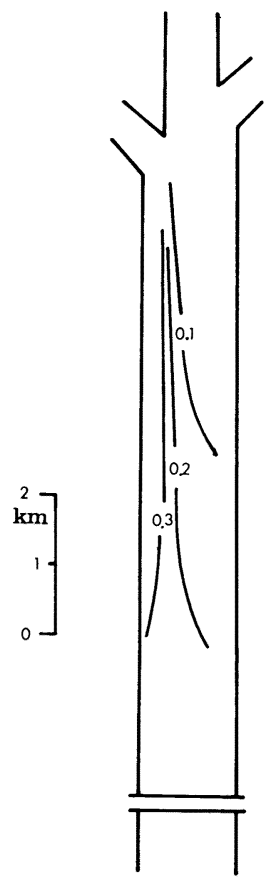

R.Katura
Fig. 5. Distribution of mixing ratio of the waters of R.Katura and R.Kizu at River Yodo in January 1985.
月の混合比の流下にともなう減少が他の測定時にくら ベて小さい，言い換えれば混合の進行が遅いのは，増 水時は流速が早いため水の混合にかかわる時間が短い ことによると考えられる(この点についての詳細な検 討は本報の域を越えるゆ光，別報で行なう）。

また，求めた三川の混合比と合流点直前の三川中の 物質濃度を用いることによって，淀川における物質濃 度を計算することができる。得られた計算值と実測值 との間には良い一致が見られた。この計算值と実測値 との間の相関係数を Table 3 に示した。下流部扣よび 支川河口近くの測点において実測値が計算值をやや上 まわる傾向が見られたが，これは支川からの負荷の影

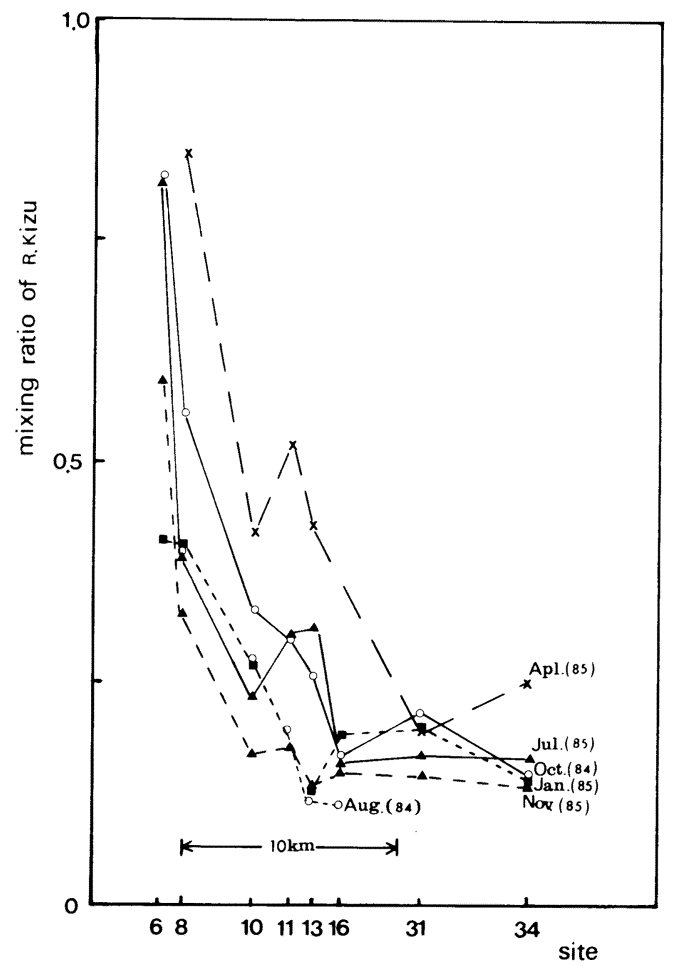

Fig. 6. The change in the mixing ratio of R.Kizu at the left side along the stream. The flow ratio of R.Kizu was as follow, August: 0.11; October: 0.17; January: 0.17; April: 0.18; November: 0.11 .

Table 3. Correlation coefficient between the calculated concentration and observed one.

\begin{tabular}{l|rrrrrr}
\hline & \multicolumn{5}{|c}{ Correlation coefficient } \\
\cline { 2 - 7 } & 84.8 & 84.10 & 85.1 & 85.4 & 85.7 & 85.11 \\
\hline $\mathrm{NH}_{3}$ & 0.957 & 0.898 & 0.798 & 0.849 & 0.526 & 0.880 \\
$\mathrm{NO}_{3}$ & 0.300 & -0.262 & 0.823 & 0.946 & 0.907 & 0.664 \\
$\mathrm{DIN}$ & 0.953 & 0.905 & 0.848 & 0.830 & 0.905 & 0.871 \\
$\mathrm{PO}_{4}$ & 0.833 & 0.848 & 0.956 & 0.800 & 0.421 & 0.723 \\
\hline
\end{tabular}


響と考えられる。実際, 最下流部および支川河口近傍 の測点を除いた場合, 計算値と実測値との間の相関係 数は Table 3 中の值に比べより大きな值が得られた。

\section{謝辞}

採水等にご協力いただいた多くの方々および流量を 計算いただいた木藤耕一氏に厚くお礼申し上げすす。

\section{摘 要}

淀川に招いて水質調査を行ない，水の混合・拡散に ついて検討した。淀川に打いては三川（木津川，宇治 川, 桂川）合流後, 合流点から約 $13 \mathrm{~km}$ 下流まで河川 横断方向に明瞭な濃度分布が認められた。この濃度分 布を支配する淀川における河川水の混合・抎散につい て検討した。

物質の保存性および三川以外からの流入負荷の小さ いことを確認し， $\mathrm{Na}$ (あるいは $\mathrm{K}$ ) および $\mathrm{SiO}_{2}$ 濃度 を混合の指標として用いらることを確かめた。これら 二つの指標を用いることによって，淀川における河川 水の混合について容易に知ることができた。求めた混 合比の妥当性を河川流量比によって確かめることがで きた。また，求めた混合比は淀川に打ける $\mathrm{NH}_{3}$ および $\mathrm{PO}_{4}$ 等の濃度分布をよく再現した。

\section{文献}

AIZAKI, (1985) Removal and excretion of dissolved organic matter by periphyton community grown in eutrophic river water, Jpn. J. Limnol., $46: 159$ -168 .

南部䍧一（1960：河川水中の自浄作用と污染度分布に 関する研究. 京都大学学位論文.

大阪工業大学 応用化学研究部 (1985) 桜花, $26: 15$, 24.

Antia, N. J., C. D. McAllister, T. R. Parsons, K. Stephens and J. D. H. Strickland. (1963) Further measurements of primary production using a large-volume plastic sphere. Limnol. Oceanogr. 8, 166-183.

（著者：五百井正樹・串部宏之・北田忠義・建部渉・ 前田礼造・人見宗男, 大阪市立大学工学部, $\overline{\mathbf{T}} 558$ 大 阪市住吉区杉本 3-3；Masaki IoI, Hiroyuki KusHIBE, Tadayoshi Kitada, Wataru Tatebe, Reizo Maeda and Muneo Hiтomi, Faculty of Engineering, Osaka City University, Sugimoto 3-3, Sumiyoshi-ku, Osaka 558) 